\title{
Front Matter: Volume 7060
}

, "Front Matter: Volume 7060," Proc. SPIE 7060, Current Developments in Lens Design and Optical Engineering IX, 706001 (24 September 2008); doi: 10.1117/12.806323

SPIE Event: Optical Engineering + Applications, 2008, San Diego, California, United SPIE. States 


\section{PROCEEDINGS OF SPIE}

\section{Current Developments in Lens Design and Optical Engineering IX}

Pantazis Z. Mouroulis

Warren J. Smith

R. Barry Johnson

Editors

11-12 August 2008

San Diego, California, USA

Sponsored and Published by

SPIE 
The papers included in this volume were part of the technical conference cited on the cover and title page. Papers were selected and subject to review by the editors and conference program committee. Some conference presentations may not be available for publication. The papers published in these proceedings reflect the work and thoughts of the authors and are published herein as submitted. The publisher is not responsible for the validity of the information or for any outcomes resulting from reliance thereon.

Please use the following format to cite material from this book:

Author(s), "Title of Paper," in Current Developments in Lens Design and Optical Engineering IX, edited by Pantazis Z. Mouroulis, Warren J. Smith, R. Barry Johnson, Proceedings of SPIE Vol. 7060 (SPIE, Bellingham, WA, 2008) Article CID Number.

ISSN 0277-786X

ISBN 9780819472809

Published by

SPIE

P.O. Box 10, Bellingham, Washington 98227-0010 USA

Telephone +1 3606763290 (Pacific Time) · Fax +1 3606471445

SPIE.org

Copyright (C) 2008, Society of Photo-Optical Instrumentation Engineers

Copying of material in this book for internal or personal use, or for the internal or personal use of specific clients, beyond the fair use provisions granted by the U.S. Copyright Law is authorized by SPIE subject to payment of copying fees. The Transactional Reporting Service base fee for this volume is $\$ 18.00$ per article (or portion thereof), which should be paid directly to the Copyright Clearance Center (CCC), 222 Rosewood Drive, Danvers, MA 01923. Payment may also be made electronically through CCC Online at copyright.com. Other copying for republication, resale, advertising or promotion, or any form of systematic or multiple reproduction of any material in this book is prohibited except with permission in writing from the publisher. The CCC fee code is 0277-786X/08/\$18.00.

Printed in the United States of America.

Publication of record for individual papers is online in the SPIE Digital Library.

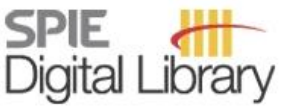

SPIEDigitalLibrary.org

Paper Numbering: Proceedings of SPIE follow an e-First publication model, with papers published first online and then in print and on CD-ROM. Papers are published as they are submitted and meet publication criteria. A unique, consistent, permanent citation identifier (CID) number is assigned to each article at the time of the first publication. Utilization of CIDs allows articles to be fully citable as soon they are published online, and connects the same identifier to all online, print, and electronic versions of the publication. SPIE uses a six-digit CID article numbering system in which:

- The first four digits correspond to the SPIE volume number.

- The last two digits indicate publication order within the volume using a Base 36 numbering system employing both numerals and letters. These two-number sets start with 00, 01, 02, 03, 04, 05 , $06,07,08,09,0 A, O B \ldots$. OZ, followed by 10-1Z, 20-2Z, etc.

The CID number appears on each page of the manuscript. The complete citation is used on the first page, and an abbreviated version on subsequent pages. Numbers in the index correspond to the last two digits of the six-digit CID number. 


\section{Contents}

vii Conference Committee

ix Dedication to Warren J. Smith

\section{SESSION 1 FABRICATION}

706002 Low-scatter bare aluminum optics via chemical mechanical polishing [7060-01]

K. J. Moeggenborg, C. Barros, S. Lesiak, N. Naguib, S. Reggie, Cabot Microelectronics Corp. (United States)

706006 Forces acting between polishing tool and workpiece surface in magnetorheological finishing [7060-05]

M. Schinhaerl, Univ. of Applied Sciences Deggendorf (Germany) and Univ. of the West of England (United Kingdom); C. Vogt, A. Geiss, Univ. of Applied Sciences Deggendorf (Germany); R. Stamp, Univ. of the West of England (United Kingdom); P. Sperber, Univ. of Applied Sciences Deggendorf (Germany); L. Smith, G. Smith, Univ. of the West of England (United Kingdom); R. Rascher, Univ. of Applied Sciences Deggendorf (Germany)

706007 Material removal study at silicon nitride molds for the precision glass molding using MRF process [7060-06]

A. Geiss, Univ. of Applied Sciences Deggendorf (Germany) and Alexander Dubcek Univ. of Trencin (Slovakia); R. Rascher, Univ. of Applied Sciences Deggendorf (Germany);

J. Slabeycius, Alexander Dubcek Univ. of Trencin (Slovakia); M. Schinhaerl, P. Sperber,

F. Patham, Univ. of Applied Sciences Deggendorf (Germany)

\section{SESSION 2 LENS DESIGN I}

706008 Design and fabrication of low-cost thermal imaging optics using precision chalcogenide glass molding [7060-07]

G. Curatu, LightPath Technologies (United States)

706009 Day and night security camera [7060-08]

M. Laikin, Laikin Optical Corp. (United States); G. Kweon, Y. Choi, Honam Univ. (South Korea)

$7060 \mathrm{OA}$ High-resolution UV relay lens for particle size distribution measurements using holography [7060-09]

R. M. Malone, G. A. Capelle, B. C. Cox, B. C. Frogget, M. Grover, M. I. Kaufman, National Security Technologies, LLC (United States); P. Pazuchanics, D. S. Sorenson, Los Alamos National Lab. (United States); G. D. Stevens, A. Tibbitts, W. D. Turley, National Security Technologies, LLC (United States)

7060 OB New tools for the lens designer [7060-10]

D. C. Dilworth, Optical Systems Design, Inc. (United States) 


\section{SESSION $3 \quad$ LENS DESIGN II}

7060 0C Optical design of reflective wide-field cameras (Invited Paper) [7060-11]

J. Sasian, College of Optical Sciences, Univ. of Arizona (United States)

7060 OD Five-lens corrector for Cassegrain-form telescopes [7060-12]

M. R. Ackermann, Sandia National Labs. (United States); J. T. McGraw, P. C. Zimmer, The Univ. of New Mexico (United States)

7060 OE Material selection for color correction in the short-wave infrared [7060-13]

R. H. Shepard III, FLIR Systems (United States); S. W. Sparrold, Edmund Optics (United States)

7060 OF Correctly making panoramic imagery and the meaning of optical center [7060-42]

R. B. Johnson, Alabama A\&M Univ. (United States)

SESSION 4 APPLICATIONS

$7060 \mathrm{OH} \quad$ Automated design and fabrication of ocular optics [7060-16]

M. Gutin, O. Gutin, Applied Science Innovations, Inc. (United States)

\section{SESSION 5 INSTRUMENTS AND TECHNIQUES}

7060 OL 3D imaging from theory to practice: the Mona Lisa story (Invited Paper) [7060-20] F. Blais, L. Cournoyer, J.-A. Beraldin, M. Picard, National Research Council Canada (Canada)

7060 ON Design of a discrete scan laser focusing system with a ring grating scan element [7060-22] J. M. Rodgers, Optical Research Associates (United States)

706000 Development and optical testing of the camera, hand lens, and microscope probe with scannable laser spectroscopy (CHAMP-SLS) [7060-23]

G. S. Mungas, Y. Gürsel, C. A. Sepulveda, M. Anderson, C. La Baw, K. R. Johnson, Jet Propulsion Lab. (United States); M. Deans, NASA Ames Research Ctr. (United States); L. Beegle, J. Boynton, Jet Propulsion Lab. (United States)

$7060 \mathrm{OP} \quad$ Lens design and system optimization for foveated imaging [7060-24]

G. Curatu, LightPath Technologies (United States); J. E. Harvey, Univ. of Central Florida (United States) 
$70600 Q \quad$ Advanced techniques for computer-controlled polishing [7060-43]

M. Schinhaerl, Univ. of Applied Sciences Deggendorf (Germany) and Univ. of the West of England (United Kingdom); R. Stamp, Univ. of the West of England (United Kingdom); E. Pitschke, Univ. of Applied Sciences Deggendorf (Germany) and Univ. of the West of England (United Kingdom); R. Rascher, Univ. of Applied Sciences Deggendorf (Germany); L. Smith, G. Smith, Univ. of the West of England (United Kingdom); A. Geiss, P. Sperber, Univ. of Applied Sciences Deggendorf (Germany)

7060 OS Design efficiency of 3188 optical designs [7060-26]

O. Cakmakci, J. P. Rolland, CREOL/College of Optics \& Photonics/Univ. of Central Florida (United States); K. P. Thompson, J. Rogers, Optical Research Associates (United States)

7060 OT High resolution wavefront measurement of aspheric optics [7060-27]

I. Erichsen, S. Krey, J. Heinisch, A. Ruprecht, E. Dumitrescu, Trioptics GmbH (Germany)

7060 OU Recent advances in the modulation transfer function testing of detector arrays [7060-28]

A. D. Ducharme, Univ. of Central Florida (United States)

\section{SESSION 7 THEORY AND DESIGN}

$7060 \mathrm{OV}$ Wavefront generated by reflection of a plane wave from a conic section [7060-29] J. A. Hoffnagle, IBM Almaden Research Ctr. (United States); D. L. Shealy, Univ. of Alabama at Birmingham (United States)

7060 OY Display system analysis with critical polarization elements in a non-sequential ray tracing environment [7060-32]

J. A. Herlocker, J. Jiang, K. J. Garcia, Breault Research Organization (United States)

\section{POSTER SESSION}

706010 An optically passive athermal infrared optical system [7060-34]

H. Li, M. Shen, Institute of Optics and Electronics (China)

706013 Aspherical optics design for minimal spherical aberration in vision correction of human eyes [7060-37]

M. Jiang, Shanghai Jiao-tong Univ. (China); J. T. Lin, National Taiwan Univ. (Taiwan);

C. Zhou, Q. Ren, Shanghai Jiao-tong Univ. (China)

706015 Modeling diffractive optical elements in hybrid systems with the effect of the material dispersion [7060-39]

H. Zhang, Changchun Institute of Optics, Fine Mechanics and Physics (China) and Graduate School of the Chinese Academy of Sciences (China); H. Liu, Z. Lu, H. Zhang, Changchun Institute of Optics, Fine Mechanics and Physics (China); Z. Ni, Aviation Univ. of Air Force (China) 
706017 The design, construction, and characterization of a solid elastic lens [7060-41]

A. Santiago-Alvarado, Univ. Tecnológica de la Mixteca (Mexico); S. Vazquez-Montiel, Instituto Nacional de Astrofísca, Óptica y Electrónica (Mexico); F. Iturbide-Jiménez, R. Arriaga-Martinez, J. Gonzalez-Garcia Univ. Tecnologica de la Mixteca (Mexico);

Author Index 


\title{
Conference Committee
}

\author{
Program Track Chair \\ R. John Koshel, Photon Engineering LLC (USA) and College of Optical \\ Sciences, The University of Arizona (USA) \\ Conference Chairs
}

Pantazis Z. Mouroulis, Jet Propulsion Laboratory (United States)

Warren J. Smith, Rockwell Collins Optronics (United States)

R. Barry Johnson, PanTechne Corporation (United States) and Alabama A\&M University (United States)

Program Committee

Florian Bociort, Technische Universiteit Delft (Netherlands)

Michael Chrisp, Lawrence Livermore National Laboratory (United States)

Apostolos Deslis, InPhase Technologies (United States)

Robert E. Fischer, OPTICS 1, Inc. (United States)

Virendra N. Mahajan, The Aerospace Corporation (United States)

Andrew Rakich, University of Arizona (United States)

Simon Thibault, ImmerVision (Canada)

Andrew P. Wood, QIOPTIQ (United Kingdom)

James M. Zavislan, University of Rochester (United States)

Session Chairs

1 Fabrication

James M. Zavislan, University of Rochester (United States)

2 Lens Design I

R. Barry Johnson, PanTechne Corporation (United States) and Alabama A\&M University (United States)

3 Lens Design II

Virendra N. Mahajan, The Aerospace Corporation (United States)

$4 \quad$ Applications

Pantazis Z. Mouroulis, Jet Propulsion Laboratory (United States) 
$5 \quad$ Instruments and Techniques

R. Barry Johnson, PanTechne Corporation (United States) and Alabama A\&M University (United States)

6 Optimization and Testing

Pantazis Z. Mouroulis, Jet Propulsion Laboratory (United States)

7 Theory and Design

Virendra N. Mahajan, The Aerospace Corporation (United States) 


\section{Dedication}

This conference is dedicated to the memory of Warren J. Smith. Warren was among the founding chairs of the Current Developments series that began in 1986 and a co-chair of each conference up to this one. This, however, was only one of his many accomplishments, which are well known to most lens designers and optical engineers and hardly need to be repeated here.

It is hard to find anyone else who personified lens design and optical engineering as fully as Warren. His long career of $60+$ years has exerted a major influence in the field through his books, publications, teaching, and mentoring of younger engineers. And for all his achievements and fame, he exhibited kindness, lack of pretense, and a remarkable sense of humor. As we celebrate Warren's contributions to our field, we cannot help but notice that one of our guiding lights has sadly dimmed.

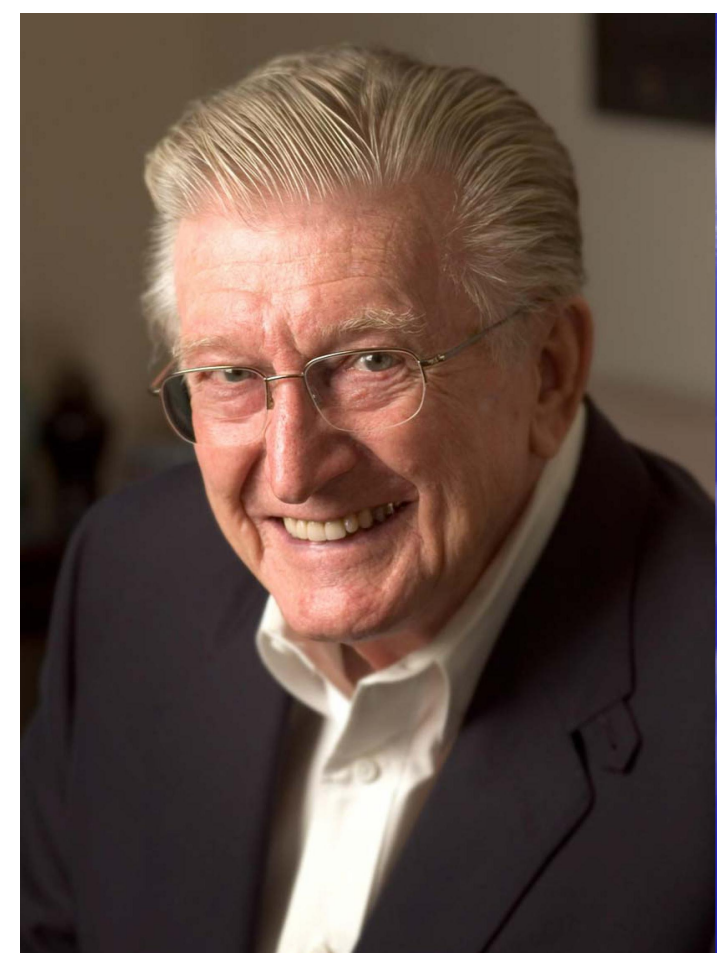

Warren J. Smith (1922-2008)

Optical engineer, educator, friend, mentor, gentleman. 
Downloaded From: https://www.spiedigitallibrary.org/conference-proceedings-of-spie on 25 Apr 2023

Terms of Use: https://www.spiedigitallibrary.org/terms-of-use 